\title{
LES FINANCES DEL CLAVARI ABAST, LÍMITS I FUNCIONAMENT (CERVERA, 1442)
}

\author{
PERE VERDÉS I PIJUAN \\ Institució Milà i Fontanals \\ (CSIC, Barcelona)
}

\begin{abstract}
SUMARI
1. Introducció.- 2. El llibre del clavari de 1442: a) Els ingressos. b) Les despeses.- 3. La diversitat de caixes: a) La receptoria. b) Altres administracions municipals.- 4. El funcionament de la clavaria: una hipòtesi de treball.- 5 . Conclusions.
\end{abstract}

\section{INTRODUCCIÓ}

L'estudi de les finances municipals a Catalunya durant l'època baixmedieval encara presenta importants llacunes i nombroses qüestions per a resoldre. Fins avui, els escassos treballs realitzats sobre aquest tema s'han limitat a mostrar els ingressos i despeses que apareixen consignats en els registres de la clavaria'. El clavari era el principal administrador dels fons

'Dins l'àmbit català, encara hi ha pocs treballs monogràfics sobre aquest tipus de font: $M$. TURULL, La hisenda $i$ el sistema financer de la paeria de Cervera. Els ingressos del Consell (1331-1333), "Ilerda», XLVII (1986), pp. 443-478; H. FORT, Aspectes econòmics de mitjan segle XIV a la vila de Reus: el llibre de clavaria de 1346-1347, dins "XXXV Assemblea Internacional d'estudiosos de Catalunya", I, Valls, 1989, pp. 367-372; J. MORELLÓ, Les finances municipals a Reus segons un llibre de clavaria de 1359, dins "Funcionament de les finances locals al llarg de la història. Actes del III Congrés internacional d'història local de Catalunya», L'Avenç, Barcelona, 1996, pp. 171-183; P. VERDÉS, Les finances municipals a

"Anuario de Estudios Medievales". 29 (1999) 
municipals a les ciutats i viles del Principat: teòricament, a les seves mans anaven a parar tots els ingressos del municipi i amb ells atenia les seves despeses $^{2}$. Sens dubte, les sèries comptables generades per aquest càrrec constitueixen un punt de referència obligat per l'anàlisi de la hisenda local, sobretot per les primeres èpoques. No obstant, la consolidació i expansió financera del municipi, com a resultat de la pressió fiscal exercida per la Corona, va tenir com a conseqüència, partir de la segona meitat del s.XIV, una ampliació i especialització administrativa. Aquest fet implica que els comptes de la clavaria, per si sols, no siguin suficients per a reconstruir les finances municipals i, com veurem, en ocasions ni tan sols registren algunes de les partides més importants.

A partir d'un cas particularment privilegiat pel que fa a les fonts, Cervera $^{3}$, intentarem il-lustrar aquest fenòmen. La confrontació d'un llibre de clavaria d'aquesta vila, concretament el de l'any 1442, amb altres sèries municipals coetànies permetrà mostrar: en primer lloc, l'abast dels ingressos i les despeses pròpies del clavari; en segon lloc, l'existència d'altres caixes que assumiren una part important de les finances municipals; i, finalment, la complexitat que assolí la institució clavarial dins el muncipi cerverí a mitjan s. XV. L'objectiu darrer del present treball, per tant, és posar de relleu la necessitat de continuar aprofundint en l'estudi de les finances locals, aprofitant la riquesa dels nostres arxius, i, al mateix temps, cridar l'atenció sobre la necessitat ser prudents a l'hora de treure conclusions d'una anàlisi

Cervera (1338-1339), dins «Funcionament de les finances locals al llarg de la història. Actes del III Congrés internacional d'història local de Catalunya», L'Avenç, Barcelona, 1996, pp. 205-214. Pel que fa al País Valencià, vegeu: M. Angels BERTRAN, L'economia municipal de Vila-real en 1362-1363, segons un llibre de clavaria, dins "I Congrés d'Història i Filologia de la Plana", Castelló, 1988, pp. 133-139; A. FURIó i F. GARCIA, La economia municipal de Alzira a fines del siglo XIV según un libro de cuentas de 1380-1381, dins «La ciudad hispànica durante los siglos XIII al XVI", vol. 2, Madrid, 1985, pp. 1611-1613; P. VICIANO, Ingrés $i$ despesa d'una vila valenciana del Quatre-cents. Les finances municipals de Castelló de la Plana (1426-1427), "Boletin de la Sociedad Castellonense de Cultura», LXVI (1990), pp. 635-664.

${ }^{2}$ La primera aproximació i síntesi sobre el clavari a Catalunya fou realitzada per J.M ${ }^{\text {a }}$ FoNT RIUS, La administración financiera en los municipios catalanes medievales, dins Historia de la Hacienda española (épocas antigua y medieval), Madrid, 1982, pp. 220-224. Sobre el clavari a Cervera, vegeu: M. TURULL, La configuració jurídica del municipi baix-medieval. Règim municipal $i$ fiscalitat a Cervera entre 1182-1430, Fundació Noguera, Barcelona, 1990, pp.419427.

${ }^{3}$ Una primera aproximació a aquestes fonts pot veure's a P. VERDÉS, Les sources fiscales et financières des municipalités catalanes aux XIVe et XVe siècles, dins D. MENJOT- M. SÁNCHEZ (ed,), La fiscalité des villes au Moyen Age (France méridionale, Catalogne et Castille). 1. Étude des sources, Éditions Privat, Toulouse, 1996, pp. 163-174 
que no hagi tingut en compte tota la documentació susceptible d'oferir informació.

Abans de res, vegem que aporta el llibre de clavaria de l'any 1442, que es conserva dins del Fons Municipal de l'Arxiu Històric Comarcal de Cervera (AHCC). El registre en qüestió és una còpia de la comptabilitat del clavari d'aquell any, que fou realitzada per l'escrivà municipal per tal de facilitar la seva fiscalització ${ }^{4}$. Com tot llibre de comptes, la font està estructurada en un apartat d'ingressos (rebudes) i un altre de pagaments (dates).

\section{a) Els ingressos}

Dins els ingressos hi ha entrades procedents de les imposicions (impost indirecte), del setzé (impost directe) i unes rebudes comunes (altres fonts de finançament).

Com és sabut, les imposicions constituïen un impost que gravava, bàsicament, la compravenda de diferents productes ${ }^{5}$. La facultat per a recaptar-lo fou concedida pel rei a la vila de Cervera - $\mathrm{i}$ a d'altres llocs reials del Principat- per a fer front als ajuts financers sol-licitats pel monarca en Parlaments i Corts generals. La continuïtat i encavalcament de les demandes durant la segona meitat del s. XIV provocaren un augment espectacular de l'endeutament censal del municipi, fins al punt d'esdevenir

\footnotetext{
${ }^{4}$ En el cas de Cervera s'han conservat exemples coetanis tant de comptes del clavari, com de llibres de clavaria. Els primers, molt rars, eren els registres comptables que portava el propi clavari, mentre els segons, més habituals, eren còpies redactades per l'escrivà de la paeria. Inicialment, el notari realitzava la còpia un cop acabat l'exercici del clavari i presentat el compte d'aquest, però des de 1402, les autoritats locals disposaren que el llibre de clavaria sigués fet paral-lelament al compte del clavari. L'objectiu de la mesura era, no sols disposar d'una reproducció en net per auditar la comptabilitat del clavari amb més comoditat, sinó també exercir un major control sobre l'activitat d'aquest ofici i estalviar una acumulació de feina a l'escrivà cada cop que finalitzava el regiment d'uns paers i s'iniciava el d'uns altres (AHCC, FM, Clavaria, 1402, f. 49 r.- 50 r. i 1403, f. 27 r.- v.).

${ }^{5} \mathrm{La}$ forma d'aquest impost indirecte ha estat estudiada recentment per P. ORTí, Les impositions municipales à la Catalogne du XIVe siècle, dins D. MENJOT- M. SÁNCHEZ (ed.), La fiscalité des villes au Moyen Age (France méridionale, Catalogne et Castille). 2. Formes de prélèvement et procédures d'imposition, Éditions Privat, Toulouse (en premsa).
} 
impossible la seva amortització. Per aquesta raó, la col·locació del producte de les imposicions al servei del deute implicà la perpetuació de facto de l'impost indirecte als llocs del domini reial ${ }^{6}$. L'any 1442 , aquest recurs fou arrendat per un any a les persones que més diners oferiren per la seva percepció i en el llibre de clavaria apareixen consignats determinats ingressos en aquest concepte ${ }^{7}$. Ara bé, per les raons que després direm, en el nostre registre només consten entrades procedents de la imposició del safrà, de restes d'altres imposicions i d'endarreriments d'anys anteriors ${ }^{8}$. En el següent quadre mostrem quina fou la composició i les xifres d'aquest capítol d'ingressos del clavari:

\section{L'impost indirecte en el llibre de clavaria}

\begin{tabular}{|c|c|}
\hline SAFRA & 5.311 s. 4 d.b. \\
\hline VI/VEREMA (restes) & 2.036 s. $11 \mathrm{~d} . \mathrm{b}$. \\
\hline CARN (restes) & 300 s.b. \\
\hline PEIX/PELLA (restes) & 90 s.b. \\
\hline ENDARRERIMENTS & 5.757 s. 8 d.b. \\
\hline TOTAL: & $\mathbf{1 3 . 4 9 5}$ s. 11 d.b. \\
\hline
\end{tabular}

D'altra banda, la fiscalitat directa (la talla o quèstia), com a recurs tradicional per a subvenir les despeses del municipi, gravava, de manera proporcional, el patrimoni dels vilatans. És a dir, les autoritats aplicaven una taxa per sou i per lliura sobre el valor dels bens mobles i immobles declarats

\footnotetext{
${ }^{6}$ Sobre aquest procés, vegeu: M. SÁNCHEZ i P. ORTí, La Corona en la génesis del sistema fiscal municipal en Catalunya (1300-1360), dins «Col-loqui Corona, municipis i fiscalitat a la Baixa Edat Mitjana», Institut d'Estudis Ilerdencs, Lleida, 1997, pp. 233-278. La perpetuació de les imposicions a Cervera és estudiada per P. VERDÉs, La consolidació del sistema fiscal $i$ financer municipal a mitjan S. XIV: el cas de Cervera, dins M. SÁNCHEZ (ed.), Fiscalidad real y finanzas urbanas en Cataluña (s. XIII-XV). CSIC, Barcelona, pp. 185-217.

${ }^{7}$ Un corredor municipal subhastava públicament les imposicions de la carn, del vi, de la farina, del blat, del peix, del safrà, de la llana $i$ altres matèries tèxtils, de la sabateria $i$ cuirateria, de la pelleria i blanqueria, de l'especieria, tenderia, merceria i argenteria i la imposició dels portals, ferreria i fusta. Sobre les taxes i el funcionament d'aquestes imposicions a Cervera, vegeu: M. TURULL, La configuració, pp. 436-456 i P. VERDÉs, Les imposicions a Cervera durant la segona meitat del s. XIV, dins "Col-loqui Corona, municipis i fiscalitat a la Baixa Edat Mitjana», Institut d'Estudis Ilerdencs, Lleida, 1997, pp. 383-422.

${ }^{8}$ En realitat existeix una altra sèrie del mateix any dins el fons municipal, on apareixen els arrendaments de totes i cadascuna de les imposicions que habitualment es recaptaven a la vila (AHCC, FM, Actes i Negocis, 1438-1445).
} 
pels veïns 9 . No obstant, l'any 1439 , després de certes tensions polítiques internes, el consell va decidir establir, durant 10 anys, un impost alternatiu que gravaria la renda ${ }^{10}$. El nou recurs s'anomenà setzé o compartiment $\mathrm{i}$ també apareix anotat en els ingressos de la clavaria de $1442^{11}$. A més, cal sumar a aquest capítol la contribució dels eclesiàstics ${ }^{12}$, la venda del blat recaptat pel setzé de l'any anterior ${ }^{13}$ i alguns endarreriments. La distribució entre els diferents conceptes és la següent:

${ }^{9} L$ 'impost directe sobre el patrimoni a Cervera ha estat ben estudiat per M. TURULL, La configuració, pp. 493-525. Els darrers treballs de síntesi sobre aquest tema a Catalunya són obra de J. MORELLó, Notes sobre el funcionament de la fiscalitat directa a la baixa edat mitjana, «Butlletí de la Societat Catalana d'Estudis Històrics", 6 (1995), pp. 61-80 i M. TURULL, El impuesto directo en los municipios catalanes medievales, dins Finanzas y fiscalidad municipal, «V Congreso de Estudios Medievales", Fundación Sánchez Albornoz, León, 1997, pp. 74-133.

${ }^{10} \mathrm{La}$ reina Maria, esposa i lloctinent del rei Alfons IV, confirmava la decisió del Consell cerverí en una provisió datada el 2 de maig de 1439 (ACA, C, reg. 3134, f. 59 r.-v.). Aquesta modalitat fiscal ja havia estat emprada a Cervera anteriorment (M. TURULL, La configuració.... pp. 521-526) i ha estat documentada i estudiada a nivell de tot Catalunya per J. MORELLó, Els impostos sobre la renda a Catalunya: redelmes, onzens $i$ similars, "Anuario de Estudios Medievales», 27 (1997), pp. 903-968.

"La forma d'aquest impost és una mica complexa, ja que. en realitat, es tractava d'un impost mixte sobre la renda $i$ el patrimoni. El total a recaptar cada any a la vila era calculat pels regidors en base a l'impost directe proporcional sobre el patrimoni (talla o quèstia) que fins llavors s'havia percebut habitualment. Un cop calculat, l'any 1442, cada contribuent havia de pagar una setzena part de la collita de cereal, 4 d.b. per somada de verema de mul i 2 d.b per somada d'ase, 6 d.b. per mitgera de safrà i una desena part de les rendes censals (censos emfitèutics i censals morts) (AHCC, FM, Actes i Negocis, 1398-1585, plec 1442). En cas que la quantitat pagada pel contribuent per la seva renda sobrepassés la suma taxada pel seu patrimoni, l'excés no li seria retornat. En canvi, si el contribuent no posseïa renda agrària o aquesta no arribava a la suma taxada sobre el patrimoni, hauria de pagar la diferència en metàl-lic; és el que s'anomenava guanyables. El terme setzé que dóna nom a l'impost procedia de la taxa aplicada sobre la collita de cereal i el de compartiment del fet de repartir la quantitat a recaptar de la manera damunt explicada. L'impost sobre la renda a Cervera durant el s. XV serà tractat en la meva tesi doctoral, on esperem poder detallar molt més el seu funcionament.

'2El tema de la contribució dels eclesiàstics pel seu patrimoni encara no ha estat ben estudiat a Cervera. Tot $i$ això, podem suposar que els clergues arribaren a un acord amb les autoritats municipals per contribuir en el compartiment de manera similar a la dels laïcs. La única distinció seria la base sobre la qual es calculava el que pertocava pagar a cada religiós, ja que, tradicionalment, només havien estat sotmesos a una taxa de 4 sous per cada 1.000 de bens immobles (M. TURULL, La configuració, pp. 542-543).

${ }^{13}$ Les autoritats locals, en una iniciativa on es combinaven els interessos fiscals del municipi i la preocupació pel proveïment de la vila, recaptaven únicament en espècie l'impost sobre les collites de cereal i l'emmagatzemaven. Aquest fet permetia tenir un estoc d'aquell producte per fer front a possibles caresties i, si aquestes no es produien, seria venut durant la primera meitat de l'any següent, quan pujaven els preus i podia fer-s'hi negoci. 


\section{L'impost directe en el llibre de clavaria}

\begin{tabular}{|r|c|}
\hline COMPARTIMENT & 17.917 s. 9 d.b. \\
\hline ECLESIÁSTICS & 681 s. 4 d.b. \\
\hline SETZÉ (1441) & 4.354 s. 9 d.b. \\
\hline ENDARRERIMENTS & 3.085 s. 2 s.b. \\
\hline TOTAL: & $\mathbf{2 6 . 0 3 9}$ s.b. \\
\hline
\end{tabular}

Finalment, el capítol dels ingressos es completa amb un apartat miscel-lani de rebudes comunes ${ }^{14}$, on cal destacar l'apartat de veïnatges. Diversos individus o col-lectius sol-licitaren ser admesos com a veïns de Cervera per tal de gaudir dels seus privilegis i protecció. El compromís no implicava necessàriament l'obligació de residir a la vila, però, a canvi, els sol-licitants haurien d'acudir a l'host local en cas de necessitat i pagar anualment certa quantitat pactada amb el municipi ${ }^{15}$. Durant la primera meitat del s. XV, el nombre de veïnatges, sobretot de comunitats locals, augmentà de manera molt considerable $\mathrm{i}$, en conseqüència, també ho feren els ingressos per aquest concepte ${ }^{16}$. La resta de rebudes comunes correponien, principalment, a antics administradors la vila que retornaven diners després de retre comptes de llur gestió ${ }^{17}$. Les quantitats restituïdes l'any 1442, els veïnatges i altres ingressos menors foren:

\section{Les rebudes comunes en el llibre de clavaria}

\begin{tabular}{|c|c|}
\hline VEİNATGES & $1.216 \mathrm{~s} .10{\mathrm{~d} . \mathrm{b}^{18}}^{18}$ \\
\hline ADMINISTRACIÓ & $2.037 \mathrm{~s} .11 \mathrm{d.b}$. \\
\hline
\end{tabular}

\footnotetext{
${ }^{14}$ Dins el llibre de clavaria, tots els endarreriments estan inclosos en les rebudes comunes però, en aquest treball, hem cregut preferible incloure'ls, segons la seva naturalesa, en el capítol corresponent d'impost directe, indirecte o altres ingressos.

${ }^{15}$ Sobre el veïnatge a Cervera, vegeu: A. DuRAN, Llibre de Cervera, Curial, Barcelona, 1977, pp. 91-99; J.M ${ }^{\text {a }}$ LLOBET, El veïnatge de Ponts amb Cervera durant la primera meitat del segle XV, «Palestra Universitaria», 4 (1989), pp. 101-114: M. TURULL, La configuració, pp. 348-355.

${ }^{16} \mathrm{~L}$ 'any 1434 , per exemple, el municipi cerveri donava una relació al recaptador dels veïnatges que pujava a 170 Il.b. (AHCC, FM, Veïnatge, f. 129 r.-131 r.).

${ }^{17}$ El clavari de l'any anterior, per exemple, retornava 13 II. 2 s. 5 d.b. després de retre comptes (AHCC, FM, Clavaria, 1442, f. 21 r.).

${ }^{18}$ Dins dels ingressos de veïnatges 39 II. 18 s. 10 d.b. corresponien a deutes i la resta, 20 II. 18 s.b., eren d'aquell any.
} 


\begin{tabular}{|r|c|}
\hline ALTRES & $326 \mathrm{~s} .1 \mathrm{~d} . \mathrm{b} .^{19}$ \\
\hline TOTAL: & $\mathbf{3 . 5 8 0}$ s. $10 \mathrm{~d} . \mathrm{b}$. \\
\hline
\end{tabular}

Així doncs, els ingressos de Cervera, segons el llibre de clavaria de 1442 , procedien en la seva major part de l'impost directe, que representava el $60 \%$, i de l'impost indirecte, amb més d'un $30 \%$, mentre que la resta no arribava al $10 \%$.

Total d'ingressos del llibre de clavaria

\begin{tabular}{|r|c|c|}
\hline IMPOST DIRECTE & 26.039 s.b. & $60 ' 39 \%$ \\
\hline IMPOST INDIRECTE & 13.495 s. 11 d.b. & 31 '30\% \\
\hline REBUDES COMUNES & 3.580 s. 10 d.b. & $8^{\prime} 30 \%$ \\
\hline TOTAL: & $\mathbf{4 3 . 1 1 5}$ s. 9 d.b. & $99 ' 99 \%$ \\
\hline
\end{tabular}

Altres aspectes relatius a les rebudes que cal destacar són, per exemple, la importància de les entrades procedents d'endarreriments i, aparentment, l'absència del recurs a l'endeutament durant aquesta anualitat. Respecte a la primera circumstància, cal assenyalar que més del $35 \%$ dels ingressos corresponen a endarreriments i més del $25 \%$ eren de l'any 1441 . Pel que fa a la manca d'endeutament, el clavari de 1442 només fa referència al retorn de bestretes en l'apartat de despeses, concretament a $1.860 \mathrm{~s}$. 6 d.b. que li foren avançats sense interés ${ }^{20}$. A continuació pot veure's quina era la naturalesa dels endarreriments de l'exercici estudiat, així com el pes relatiu dels ingressos restants de l'any anterior.

Total d'endarreriments en el lllibre de clavaria

\begin{tabular}{|c|c|c|}
\hline CONCEPTE & TOTAL & I441 \\
\hline IMPOST DIRECTE & 7.439 s. 11 d.b. & 5.232 s. 8 d.b. \\
\hline IMPOST INDIRECTE & 5.757 s. 8 d.b. & 5.263 s. 8 d.b. \\
\hline
\end{tabular}

\footnotetext{
${ }^{19}$ Aquest capítol inclou 14 11. 18 s. 9 d.b. que també eren deutes d'anys anteriors.

${ }^{20} \mathrm{El}$ clavari quan realitzava un pagament indicava, al principi, si aquells diners eren retornats a algú que els havia bestret anteriorment per pagar aquella despesa.
} 


\begin{tabular}{|c|c|c|}
\hline REBUDES COMUNES & 3.135 s. 6 d.b. & 896 s. 3 d.b. \\
\hline TOTAL: & 16. 333 s. 1 d.b. & 11.392 s. 7 d.b. \\
\hline
\end{tabular}

\section{b) Les despeses}

Les dates apareixen dividides dins el llibre de clavaria de 1442 en dos capítols: la satisfacció dels interessos de l'endeutament censal i la resta de despeses, qualificades com ordinàries $i$ extraordinàries. Aquest segon apartat inclou, barrejades, despeses derivades del funcionament de l'aparell administratiu municipal i de diverses prestacions de serveis a la comunitat.

Com ja hem dit en parlar de les imposicions, les contínues demandes reials que es produïren durant la segona meitat del s. XIV provocaren un augment espectacular de l'endeutament a llarg plaç (censals morts i violaris) del municipi. La venda de noves rendes per a fer front a la construcció de les muralles, a l'abastament blader i al finançament dels interessos del propi deute instal-laren al municipi en un endeutament gairebé estructural, que esdevingué una feixuga herència per les autoritats cerverines del $\mathrm{s} . \mathrm{XV}^{21}$. L'any 1442, el clavari pagava, en primer lloc, els interessos d'aquell any i els endarreriments d'anys anteriors $i$, molt secundàriament, amortitzava parcialment el deute i avançava alguns interessos de l'any següent ${ }^{22}$. En xifres, aquesta distribució apareix de la següent manera:

\section{L'endeutament en el llibre de clavaria}

\begin{tabular}{|r|c|}
\hline INTERESSOS (1441) & 22.903 s. 13 d.b. \\
\hline INTERESSOS (endarrer.) & 4.607 s. 7 d.b. \\
\hline INTERESSOS (avanç.) & 120 s.b. \\
\hline AMORTITZACIÓ & 1.153 s. 6 d.b. \\
\hline TOTAL: & $\mathbf{2 8 . 7 9 0 ~ s . ~} 2$ d.b. \\
\hline
\end{tabular}

El segon capítol de les despeses està format per les de caràcter administratiu. Dins aquesta partida, pot distingir-se entre els salaris que

\footnotetext{
${ }^{21} L$ 'endeutament a Cervera durant la segona meitat del s. XIV ha estat estudiat per $\mathbf{M}$. Turull (M. TURULL, La configuració, pp. 457-487) i l'anàlisi pel $\mathrm{s}$. XV serà objecte d'un capítol en la meva tesi doctoral.

${ }^{22}$ Concretament, va avançar 6 II.b. a les monges del Monestir de $S^{a}$ Clara de Cervera en un acte que podria considerar-se quasi de beneficència (AHCC, FM, Clavaria, 1442, f. 35 r.).
} 
regularment, any rere any, percebien una sèrie de càrrecs municipals i la resta de retribucions. Els salaris pagats l'any 1442 pel clavari corresponien $a^{23}:$

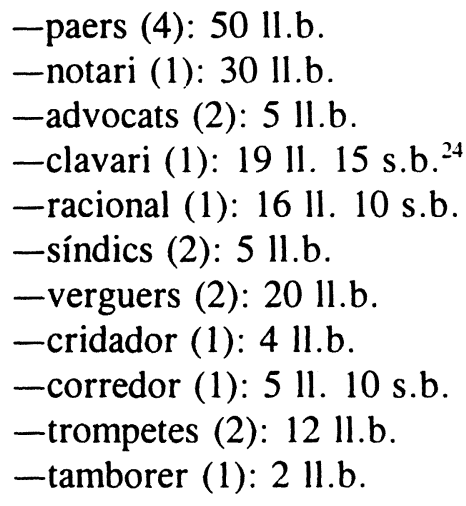

La resta de remuneracions administratives de la vila eren de tipus extraordinari i corresponien a missatgeries ${ }^{25}$, recaptació d'impostos ${ }^{26}$, gestió del deute ${ }^{27}$, despesa judicial ${ }^{28}$, oficials $^{29}$, escrivania $^{30}$, material ${ }^{31}$

\footnotetext{
${ }^{23} \mathrm{~A}$ continuació presentem una llista on consta el nom del càrrec. el nombre de membres del mateix (entre parèntesi) i el total cobrat per cadascuna de les diferents categories. Sobre les funcions d'aquests oficis, vegeu: M. TURULL, La configuració. pp. 282-307.

${ }^{24}$ El clavari no tenia un salari regular, sinó que, com veurem, l'ofici era arrendat a qui el regís per menys diners.

${ }^{25}$ Les missatgeries poden dividir-se entre les realitzades per correus $\mathrm{i}$ les dutes a terme pels representants de la vila (síndics o procuradors). Aquesta darrera partida era molt important quantitativament, però pot resultar enganyosa: les missatgeries presentaven compte apart al racional, on feien constar, desglossades, les dietes, el lloguer d'animals i altres despeses relacionades amb la comesa del seu viatge. Un cop conformades aquestes despeses, el clavari pagava la suma total i no distingia entre els diferents conceptes. L'any 1442 les despeses en correus suposaren 32 II. 19 s. 9 d.b., mentre que les de representació pujaren a 179 Il. 4 s. 1 d.b.

${ }^{26}$ Les despeses de la gestió dels impostos de l'any 1442 estaven generades, principalment, per la recaptació del serzé dels cereals; l'únic gestionat directament pel municipi. Concretament, la major part de pagaments corresponen a salaris de recaptadors d'aquell any, de collidors d'anys anteriors $\mathrm{i}$ d'emmagatzemament del cereal. Una altra despesa interessant de destacar dins aquest apartat corresponia als guardes dels portals de la muralla, que tenien la missió de controlar l'entrada de verema a la vila durant els mesos de la collita.

${ }^{27} \mathrm{La}$ gestió del deute dins la clavaria de 1442 correspon a les despeses motivades pels procuradors d'alguns creditors censalistes, que reclamaven llurs interessos quan no eren pagats dins el termini acordat; llavors, el municipi havia de fer front a les dietes d'aquests procuradors $\mathrm{i}$ a les denúncies presentades davant els oficials de la vila.
} 
i altres ${ }^{32}$. A continuació detallem a quant ascendí la despesa administrativa, tant pel que fa als salaris ordinaris com a la resta de retribucions esmentades:

\section{La despesa administrativa en el llibre de clavaria}

\begin{tabular}{|c|c|c|}
\hline SALARIS & & 3.359 s.b. \\
\hline $\begin{array}{c}\text { ALTRES } \\
\text { Missatgeries: } \\
\text { Rec. impostos: } \\
\text { Gest. deute: } \\
\text { Desp. judicial: } \\
\text { Oficials: } \\
\text { Escrivania: } \\
\text { Material: } \\
\text { No determinat: }\end{array}$ & $\begin{array}{c}4.243 \text { s. } 10 \text { d.b } \\
1.547 \text { s. } 11 \text { d.b. } \\
101 \text { s. } 6 \text { d.b } \\
364 \text { s.b. } \\
745 \text { s. } 7 \text { d.b. } \\
189 \text { s. } 7 \text { d.b. } \\
1.090 \text { s. } 5 \text { d.b. } \\
65 \text { s. } 4 \text { d.b. }\end{array}$ & 8.348 s. 4 d.b. \\
\hline & $\begin{array}{l}\text { TOTAL: } \\
\end{array}$ & 11.743 s. 4 d.b. \\
\hline
\end{tabular}

Finalment, el clavari havia de fer front a aquelles despeses derivades de la prestació de serveis a la comunitat per part del municipi. Aquests serveis eren de carácter social, econòmic, urbanístic i de seguretat. Dins de la despesa social, l'any 1442, es poden incloure serveis de tipus religiós ${ }^{33}$,

\footnotetext{
${ }^{28}$ Sota aquest epígraf hi hauria les despeses derivades dels nombrosos plets en què sovint es veia implicada la vila; concretament, hem comptabilitzat com a tals els salaris d'advocats, juristes $i$ jutges $i$ les condemnes per sentències desfavorables.

${ }^{29} \mathrm{Amb}$ el nom d'oficials designem les despeses generades pel recurs a altres instàncies administratives com ara els oficials reials (veguer i batlle) i els religiosos (degà) de la vila, així com a la pròpia cort del rei o del bisbe de Vic.

${ }^{30} \mathrm{El}$ notari de la paeria no podia fer front a totes les tasques requerides per les autoritats locals $\mathrm{i}$, per aquesta raó, és molt habitual el recurs a altres escrivans per fer contractes, traslladar documents, redactar cartes... etc.

${ }^{31}$ El paper, pergamins, cera, candeles, torxes, vestits d'oficials... conformen el miscel-lani capítol de despeses de material.

${ }^{32}$ Tots aquests aspectes de l'administració del municipi cerverí són tractats amb més profunditat per M. TURULL, La configuració, pp. 549-554.

${ }^{33}$ L'any 1442 , les despeses de les autoritats locals per serveis religiosos es reduïen a la remuneració donada a fra Joan Batlle, guàrdia del monestir dels Framenors de la vila, per les predicacions que féu durant la quaresma (AHCC, FM, Clavaria, 1442, f. 75 r.). Les predicacions quaresmals a Cervera han estat estudiades per R. MIRó, Predicar la quaresma a Cervera als segles XV $i$ XVI, dins Estudis de llengua i literatura catalanes/XXX. Miscel-lània Germà Colom, 3, Publicacions de l'Abadia de Montserrat, 1995, pp. 81-107.
} 
festiu $^{34}$, sanitari ${ }^{35}$, d'educació ${ }^{36}$ i d'abastament ${ }^{37}$. Pel que fa als serveis econòmics, la despesa es limita a les indemnitzacions pagades als arrendataris d'impostos per les pèrdues que experimentaren a conseqüència de les franqueses atorgades pels regidors als mercaders que acudien al Gran Mercat i a la fira de la vila ${ }^{38}$. Les obres, tercer capítol dels serveis comunitaris, apareixen registrades en el llibre de clavaria de 1442 com a despeses de manteniment de les muralles de la vila ${ }^{39}$, de vies públiques ${ }^{40}$, de pous $\mathrm{i}$

\footnotetext{
${ }^{34}$ Les despeses de caràcter festiu, l'any 1442, corresponien als juglars i guarniments de la festivitat del Corpus, als músics que tocaren al Gran Mercat $i$ a la fira, a premis pel joc de la ballesta $\mathrm{i}$ a les celebracions fetes per la conquesta de Nàpols. L'historiador R. Miró ha realitzat alguns estudis sobre el fenòmen lúdic a Cervera $\mathrm{i}$ a les terres de Lleida: R. MiRó, Teatre medieval $i$ modern. Universitat de Lleida, Lleida, 1996 i La processó de Corpus i els entremesos. Cervera, segles XIV-XIX, Curial Edicions Catalanes i Publicacions de l'Abadia de Montserrat, 1998. A nivell general, vegeu les "XI Jornades d'Estudis Històrics Local" (Espa i temps d'oci a la història), publicades per la Universitat de les Illes Balears, a Palma, l'any 1993 .

${ }^{35}$ Mestre Bernat Gibert, "mestre en arts de medicina”, va rebre l'any 1442 en concepte de pensió per servir a la vila 15 II.b. (AHCC, FM, Clavaria, 1442, f. 97 r.). El tema de la sanita a Cervera durant el s. XIV ha estat estudiat per M. TURULL, La configuració, pp. 355-358.

${ }^{36}$ Mestre Alonso Ollers, "batxiller en arts i en medicina", va rebre els 40 florins que la vila acostumava a donar anualment al mestre de les escoles (AHCC, FM, Clavaria, 1442, f. $71 \mathrm{r}$. i 73 r.). Les escoles de gramàtica i lògica a Cervera durant l'Edat Mitjana han estat abastament estudiades en els treballs de: A. DURAN i F. GómEZ, Las escuelas de gramática en Cervera, «Biblioteca de la Real Academia de la Buenas Letras de Barcelona», XVII (1944). pp. 5-77; AJ. SOBERANAS, Una companyia per regir les escoles de gramàtica i loggica de Cervera el curs 1440-1441, "Biblioteca de la Real Academia de las Buenas Letras de Barcelona". XXXVIII (1977-1978), pp. 169-175: M. TURULL, La configuració, pp. 358-359: J M ${ }^{\mathbf{a}}$ LLOBET Les escoles de Cervera segons els capitols per al seu regiment (1445-1693). "Palestra Universitària”. 10 (1998), pp. 33-43.

${ }^{i 7}$ Les despeses d'abastament frumentari de la població sols eren importants en moments de carestia, cosa que no passa l'any 1442 quan el clavari només pagà alguns endarreriments pe compres de blat fetes per la botiga municipal l'any anterior. Vegeu exemples de l'actuació municipal per fer front a caresties bladeres a M. TURULL, El "mal any primer". Trasbals sociopolític $i$ crisi de subsistències (1333), «Miscel-lània Cerverina», 4 (1986), pp. 43-70; P VERDÉS, La carestia de blat de 1374-1376 a Cervera, "Miscel-lània Cerverina", 12 (1998), pp 5-23.

${ }^{38}$ Els regidors locals arribaren a un acord amb els posseïdors de la lleuda $i$ pes reials- tal com acostumaven a fer cada any- per compensar-los per les franqueses atorgades als mercaders foranis que venien als dos principals aconteixements comercials que tenien lloc a la vila cada any, el Gran Mercat i la fira. Els principals estudis sobre els drets reials i l'activitat comercial a Cervera són els de P. BERTRAN, La lleuda de Cervera (segle XV), "Miscel-lània Cerverina". 2 (1984), pp. 49-66 i M. TURULL, Intercanvi comercial, fira i mercat a Cervera entre $1136 \mathrm{i}$ 1392, «Miscel-lània Cerverina», 7 (1991), pp. 19-39.

${ }^{39} \mathrm{~L}$ 'any 1442 van realitzar-se reparacions al Portal d'en Rius, situat a la muralla de la zona nord de la vila, dins el barri de Capcorral. A part, el clavari va pagar una quantitat a Pere d'Äger i Joan Roig en concepte de salari per ser "guardes de les clavegueres". Aquesta darrera despesa pot considerar-se com a ordinària, ja que cada any s'escollien una o dos persones encarregades de vetllar pel manteniment de les clavegueres construïdes per evitar que l'aigüa
} 
fonts $^{41}$ i d'altres construccions menors de caràcter civil ${ }^{42}$. En últim lloc, cal fer esment a les despeses de tipus militar, concretament, als preparatius de l'host que la vila de Cervera volia enviar contra l'abat de Ripoll ${ }^{43}$. En el següent quadre queda reflectit el pes de cadascun dels serveis prestat pel municipi dins la comptabilitat del clavari.

\section{Els serveis en el llibre de clavaria}

\begin{tabular}{|c|c|}
\hline SOCIALS & 1.254 s. 4 d.b. \\
\hline ECONÓMICS & 461 s. 8 d.b. \\
\hline OBRES & 716 s. 4 d.b. \\
\hline SEGURETAT & 224 s. 4 d.b. \\
\hline TOTAL: & 2.656 s. 8 d.b. \\
\hline
\end{tabular}

Els resultats de l'anàlisi de la despesa consignada en el llibre de clavaria de l'any 1442 són clars: el pagament dels interessos del deute constituïa la principal partida a que feia front el municipi cerverí, amb més del $65 \%$ del total. L'administració municipal ocupa el segon lloc, amb poc més del $25 \%$, i tanquen el quadre els serveis, que no arriben ni al $10 \%$.

afectés l'estructura dels murs de la vila.

${ }^{40} \mathrm{El}$ manteniment de la via pública l'any estudiat es limita a les obres realitzades pels carrers de la vila per on passaven les representacions del dia de Corpus.

${ }^{4 \mid} \mathrm{El}$ manteniment ordinari dels principals punts d'aprovisionament d'aigua de la vila era responsabilitat, tal com veïem en el cas de les clavegueres dels murs, d'uns "guardes". Així, els dos "guardes dels Pous" van rebre el seu salari, més una suma addicional per netejar-los, i també va rebre la seva remuneració el "guarda de l'Abeurador". Sobre l'ofici dels "guardes" a Cervera, vegeu: M. TURULL, La configuració, pp. 304-305.

${ }^{42} \mathrm{~L}$ 'any 1442 , el clavari va pagar a un pedrapiquer que edificà un costell on restaven lligats els que blasfemaven. També retribuí a un fuster que féu obres de manteniment a la casa del tint de la vila. No obstant, la despesa urbanística més important d'aquell any foren les obres de reforma del burdell, en les portes del qual els regidors manaren pintar $\mathrm{i}$ daurar els cèrvols de l'escut cerverí.

${ }^{43}$ Les principals despeses militars derivades de la preparació de l'host contra l'abat de Ripoll corresponien a armament (ballestes, sagetes, acer, escuts). A banda, també hi ha una petita quantitat pagada pel cerimonial de treure la bandera de la vila al portal per on hauria de sortir I'host. La defensa veïnal també és un dels capítols que mereix l'atenció de M. TURULL, $L a$ configuració, pp. 279 i 366-369. 


\section{Les despeses en el llibre de clavaria}

\begin{tabular}{|r|c|c|}
\hline DEUTE & 28.790 s. 2 d.b. & $66^{\prime} 64 \%$ \\
\hline ADMINISTRACIÓ & 11.743 s. 4 d.b. & $27^{\prime} 18 \%$ \\
\hline SERVEIS & 2.656 s. 8 d.b. & $6^{\prime} 14 \%$ \\
\hline TOTAL: & $\mathbf{4 3 . 1 9 0 \text { s. } 2 \text { d.b. }}$ & $\mathbf{9 9} 96 \%$ \\
\hline
\end{tabular}

Aquesta relació, tal com s'observa en el següent quadre, es manté també respecte als endarreriments a que va fer front el clavari d'aquell any, que suposaren prop del $15 \%$ de la despesa total:

Els endarreriments en el llibre de clavaria

\begin{tabular}{|c|c|}
\hline$\overline{D E U}=:-$ & 4.607 s. 7 d.b. \\
\hline ADMINISTRACIÓ & 987 s. 2 d.b. \\
\hline SERVEIS & 86 s. 8 d.b. \\
\hline TOTAL: & 5.681 s. 5 d.b. \\
\hline
\end{tabular}

TOTAL REBUDES (CLAVARIA)

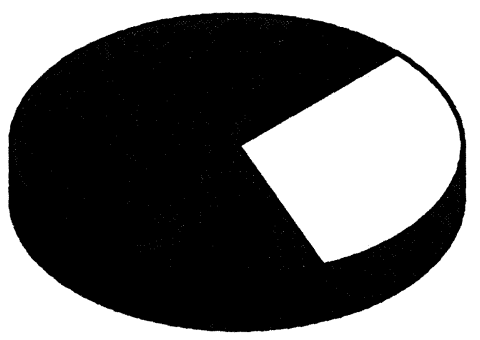

口Imp. indirecte

Imp. directe

altres 


\section{TOTAL DATES (CLAVARIA)}

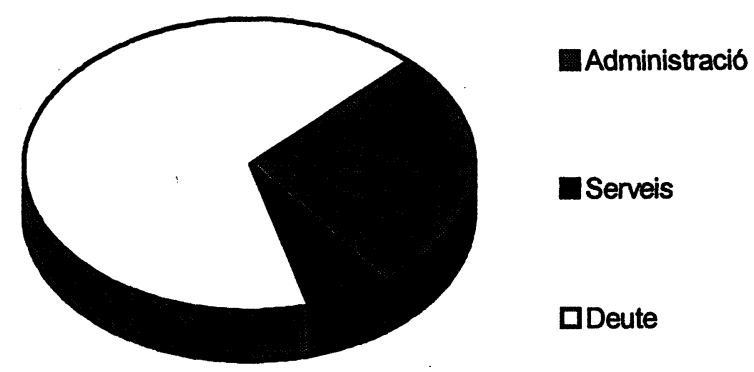

\section{LA DIVERSITAT DE CAIXES}

Aquestes són les finances del del municipi de Cervera, l'any 1442, segons les dades del llibre de clavaria. Ara bé, qui arribi a la conclusió que els ingressos durant aquell període es fonamentaven sobre l'impost directe o que les autoritats tenien un limitat interés a l'hora d'oferir serveis de la comunitat està absolutament equivocat. Tot i que la font que acabem de veure té una importància innegable, hem de tenir en compte que la clavaria coexistia amb altres administracions financeres, com ara la receptoria, l'obra de l'esglèsia, les institucions benèfiques $\mathrm{i}$ diversos càrrecs municipals que funcionaven de manera independent. Així doncs, després d'analitzar la comptabilitat del clavari és necessari ampliar la nostra perspectiva amb la informació que proporcionen aquestes altres caixes.

\section{a) La receptoria}

La receptoria era una administració dedicada a la gestió d'una part molt important de l'endeutament censal contret pel municipi cerverí, concretament amb els creditors denominats del pagament de Barcelona. En efecte, l'any 1413, després d'una suspensió de pagaments decretada per les autoritats locals dos anys abans, els creditors censalistes de la vila residents a Barcelona o a la seva rodalia, agrupats en un col-lectiu, accediren a una 
reducció de l'interés al 3’3\%. A canvi, els regidors cerverins es varen comprometre a assignar i obligar les imposicions a la satisfacció de l'esmentat interés i a l'amortització anual de 25.000 s.b. del capital prestat pels creditors de la ciutat comtal. Sols correspondrien a la vila els diners que cada any restessin després d'haver pagat als creditors barcelonins o els que aquests últims cedissin "graciosament". Això significava que una part dels ingressos - la major part de les imposicions - i una part de les despeses - el deute barceloní i la seva administració- disposarien d'una comptabilitat pròpia. La quèstia que la vila incialment pagava al rei i que, desde 1380 , pagava al ciutadà barceloní Joan Gener i als seus descendents també s'afegí al capítol de despeses per raons logístiques ${ }^{44}$. La nova administració s'anomenà receptoria (de les imposicions) i va donar lloc a una sèrie documental paral·lela a la clavaria ${ }^{45}$. La receptoria de 1442 va ingressar 31.459 s. 9 d.b. procedents de l'arrendament de l'impost indirecte d'aquell any i va despendre la mateixa quantitat per a pagar als creditors censalistes de Barcelona ${ }^{46}$. La distribució d'aquesta despesa, entre els interessos del deute, l'amortització de capitals, la quèstia pagada a Joan Gener i les despeses d'administració del receptor, és la següent:

\section{La despesa de la receptoria}

\begin{tabular}{|c|c|}
\hline INTERESSOS & 19.284 s. 6 d.b. \\
\hline
\end{tabular}

\footnotetext{
${ }^{4}$ La quèstia era un tribut que el senyor feudal (el rei en el cas de Cervera) cobrava al seus vassalls. Aquest dret, després de diverses vicissituds, passà a l'infant Joan que, l'any 1380. el vengué al cavaller barceloní Joan Gener. (M. TURULL. La configuració, pp. 528-535). El fet de ser, igual que els censalistes, un creditor de la ciutat comtal i que haguessin denviar-se-li els diners al seu domicili, feu que el pagament Joan Gener sigués inclós també dins de les despeses de la receptoria.

${ }^{45}$ Una primera aproximació a aquesta sèrie comptable pot veure's a: P. VERDÉs, Les sources fiscales..., pp. 165-166. A la resta de Catalunya s'observa una evolució idèntica $i$, des de finals del s. XIV, pot documentar-se l'existència de clavaries de censals a llocs com, per exemple, Girona (C. GUILLERÉ, Les sources financières et fiscales a Gérone à la fin du Moyen Âge. dins D. MENJOT- M. SÁNCHEZ, Op. cit., pp. 52-55), Valls (J. MORELló, Fiscalitat i finances de dues viles del Camp de Tarragona: Reus i Valls durant els segles XIV i XV. Tesi doctoral, Barcelona, 1998, I, pp. 859-861) o Castelló d’Empúries (M. SẢNCHEZ, Fiscalidad y finanzas de una villa señorial catalana: Castelló d'Empúries, 1381-1382, dins M. SÁNCHEZ (ed.), Fiscalidad real y finanzas urbanas en la Cataluña medieval, CSIC, Barcelona, 1999, pp.301362). Quelcom similar pot dir-se de València, tal com mostra R. NARBona, Finanzas municipales y patriciado urbano. Valencia a finales del Trescientos, "Anuario de Estudios Medievales", 22 (1992), pp. 488-496.

${ }^{46}$ El llibre de receptoria de 1442 no s'ha conservat, però hi ha un resum de les xifres en un registre del racional de la vila (AHCC. FM, Dates i rebudes. 1442, f. 50 v.- 51 r.).
} 


\begin{tabular}{|r|c|}
\hline \multicolumn{1}{|c|}{ AMORTITZACIÓ } & 5.000 s.b. \\
\hline QUESTIA & 6.400 s.b. \\
\hline ADMINISTRACIÓ & 775 s. 3 d.b. \\
\hline TOTAL: & $\mathbf{3 1 . 4 5 9}$ s. 9 d.b. \\
\hline
\end{tabular}

Com pot veure's en el quadre que presentem tot seguit, les xifres que sobre les finances municipals proporcionava la clavaria restarien totalment incomplertes sense tenir en compte la receptoria. El total d'ingressos i despeses augmenta més de 30.000 s.b i quasi es dobla. Aiximateix, el resultat d'afegir l'impost indirecte percebut pel receptor al que ja hem documentat pel clavari converteix aquest recurs en el veritable pilar de la hisenda local, amb més del $60 \%$ dels ingressos. Pel que fa a les despeses, el protagonisme de l'endeutament augmenta encara més i la satisfacció d'interessos i devolució de capitals superen el $70 \%$ del total. També cal destacar el pagament de la quèstia, que suposa una quantitat gens menyspreable i que constitueix, per si sola, una nova partida que anomenarem "transferències". Finalment, pot observar-se un lleuger augment del capítol administratiu amb la inclusió de les despeses de gestió de l'endeutament ${ }^{47}$.

Total d'ingressos (clavaria + receptoria)

\begin{tabular}{|r|c|c|}
\hline IMPOST INDIRECTE & 44.955 s. 8 d.b. & $60^{\prime} 28 \%$ \\
\hline IMPOST DIRECTE & 26.039 s.b. & $34^{\prime} 91 \%$ \\
\hline REB. COMUNES & 3.580 s. 10 d.b. & $4^{\prime} 80 \%$ \\
\hline TOTAL: & $\mathbf{7 4 . 5 7 5}$ s. 6 d.b. & $99^{\prime} 99 \%$ \\
\hline
\end{tabular}

Total de despeses (clavaria + receptoria)

\begin{tabular}{|r|c|c|}
\hline DEUTE & 53.074 s. 8 d.b. & $71^{\prime} 09 \%$ \\
\hline ADMINISTRACIÓ & 12.518 s. 7 d.b. & $16^{\prime} 76 \%$ \\
\hline SERVEIS & 2.656 s. 8 d.b. & $3{ }^{\prime} 55 \%$ \\
\hline TRANSFERĖNCIES & 6.400 s.b. & $8^{\prime} 57 \%$ \\
\hline TOTAL: & $\mathbf{7 4 . 6 4 9}$ s. 11 d.b. & $99^{\prime} 97 \%$ \\
\hline
\end{tabular}

\footnotetext{
${ }^{47}$ Les despeses d'administració de la receptoria estaven formades pel salari del receptor de l'impost indirecte a Cervera ( 8 II. 5 s.b.), el distribuïdor dels diners a Barcelona $(11 \mathrm{ll} . \mathrm{b}$.) $\mathrm{i}$ el notari (6 II. 17 s. 6 d.b.) (AHCC, FM, Dates i rebudes, 1442, f. 51 r.)
} 
TOTAL REBUDES

3

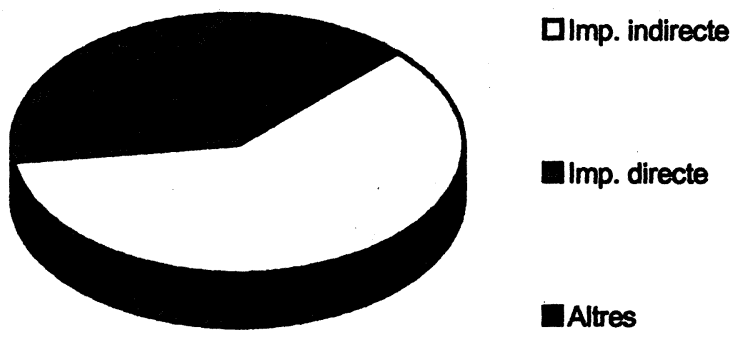

TOTAL DATES

4

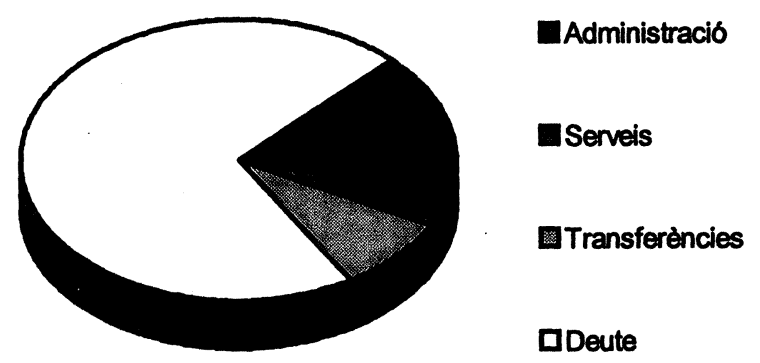




\section{b) Altres administracions municipals}

Sens dubte, el fet d'haver pogut trobar les xifres de la receptoria de l'any 1442 permet esmenar en gran mesura la visió esbiaixada que proporcionava, per si sola, la clavaria. Malauradament, no hem tingut tanta sort pel que fa a la resta d'administracions financeres - molt menys importants econòmicament - que funcionaren a la vila de manera coetània. Els comptes d'aquestes altres caixes, d'haver-se conservat, permetrien rectificar, sobretot, una percepció errònia que proporcionava el llibre de clavaria: la manca d'inversió de les autoritats locals en els diferents serveis comunitaris.

Una d'aquestes administracions era la de l'obra de l'esglèsia parroquial de Santa Maria, la construcció de la qual s'havia iniciat al s. XIII $\mathrm{i}$ es perllongà durant les tres centúries següents. Tot i les aportacions puntuals del municipi a la construcció (reflectides als llibres de clavaria), aquesta disposava d'uns recursos propis que eren esmerçats en l'edificació del temple per uns obrers escollits anualment pels regidors ${ }^{48}$. Com hem apuntat, la sèrie de comptes de l'obra quasi no s'ha conservat, però cal tenir en compte la seva existència, sobretot a l'hora de valorar la despesa municipal en obres.

En aquest sentit, també és important fer esment a les institucions municipals de caràcter benèfic. Com hem vist, l'any 1442 no hi havia cap referència a beneficència en el llibre de clavaria. Volia dir això que l'assitència als necessitats no era una preocupació pel municipi cerverí? Moltes vegades la prestació d'aquest tipus de serveis responia a accions circumstancials, però hi ha notícies sobre el funcionament regular d'administracions paral leles dedicades a aquesta comesa. El Consell cerverí escollia anualment procuradors dels hospitals, dels "infants gitats", dels bacins o del "Censal de la Caritat" que estaven obligats a retre comptes per la seva gestió $^{49}$. Les prestacions d'aquestes institucions, doncs, juntament amb les causes pies instituïdes per deixes testamentàries $i$ les aportacions extraordinàries del municipi, cobrien el capítol de la caritat a la vila ${ }^{50}$.

\footnotetext{
${ }^{48} \mathrm{M}$. TURULl, La configuració, pp. 556-558.

${ }^{49} \mathrm{M}$. TURULL, La configuració, pp. 360.

${ }^{50}$ Algunes de les principals causes pies instituïdes en deixes testamentàries a Cervera han estat estudiades per F.Xavier RIVERA, Ramon Serra el vell: poder, condició social i caritat d'un mercader cerverí a les acaballes del segle XIV, «Miscel-lània Cerverina», 10 (1996), pp. 37-70
} 
L'enumeració d'altres caixes es completa amb uns oficis municipals que oferien serveis de caràcter econòmic a la població i també retien comptes específics per la seva gestió. D'una banda, els mostassafs, pesadors, mesuradors i veedors dels diferents oficis (draps, llana, pells, argent, cera...), que regulaven la manufactura i comerç a la població a canvi d'una sèrie de taxes i l'assignació de les multes que se'n derivaven ${ }^{51}$. De l'altra, els guardians del terme o els del bestiar i els partidors de les aigües, que feien una tasca similar en l'àmbit agropecuari ${ }^{52}$.

Certament, el problema de la manca de fonts per a estudiar les administracions que acabem d'enumerar limiten el nostre anàlisi de les finances municipal. El problema, però, encara s'agreuja més degut a l'existència de certes actuacions del municipi a l'hora de realitzar algunes tasques d'interés general a la vila, que no deixen cap tipus de rastre comptable. Concretament, ens referim a la prestació de serveis personals per part de la població i als sistemes de gestió indirecta habituals en la recaptació d'impostos

Els serveis personals no han estat gaire estudiats, però sabem que els cerverins realitzaven tota una sèrie de treballs no remunerats en benefici de la comunitat o el senyor ${ }^{53}$. La població, de manera individual o organitzada en unitats de 10-50 persones (desenes i cinquantenes), restava obligada a una

i L'administració de l'Hospital de Castelltort l'any 1492, un segle després de la seva fundació, "Miscel-lània Cerverina", 11 (1997), pp. 95-122.

${ }^{51}$ Un exemple de la comptabilitat del mostassaf pel cas de Barcelona pot veure's a J. COMELLAS, El mercat barceloni a través de la mostassaferia a principis del $s$. XV dins uIr Col-loqui d'Història de l'Alimentació a la Corona d'Aragóm. vol. 2, Intitut d'Estudis Ilerdencs, Lleida, 1995, pp. 95-107.

${ }^{52}$ Una primera aproximació a aquests càrrecs pot trobar-se a M. TURULL. La configurcició, pp. 294-307. Amb tot, el tema de la regulació econòmica a la vila de Cervera $i$ a altres llocs de Catalunya pateix encara un important dèficit de treballs.

${ }^{53}$ Sobre aquest tipus de serveis feudals o comunitaris, vegeu: J.M a FONT RIUS, Origenes del régimen municipal en Cataluña, dins Estudis sobre els drets $i$ institucions locals en la Catalunya medieval, Universitat de Barcelona, Barcelona, 1985, pp. $281-560$ (pp. 384-385); V. FERro, El Dret públic Català. Les Institucions a Catalunya fins al Decret de Nova Planta, Eumo Editorial, Vic, 1987, p. 141; J.M. PONS GuRI, Compendi sobre els drets dels castells termenats (segles XIII-XV), dins "Recull d'estudis d'història jurídica catalana», vol III, Fundació Noguera, Barcelona, 1989, pp. 339-352. Per Cervera, els serveis militars de la població són esmentats per M. TURULL, La configuració, pp. 366-369. 
sèrie de prestacions que se centraven, bàsicament en dos àmbits: les obres públiques i la seguretat. Dins les obres públiques hi havia treballs de manteniment de la infraestructura viària ${ }^{54}$, hidràulica ${ }^{55}$ o defensiva ${ }^{56}$. Respecte a les obligacions militars, cal destacar el "sometent", la participació en l'host veïnal o els serveis de vigilància requerits en el marc de conjuntures bèl-liques ${ }^{57}$. Desgraciadament, no hi ha dades concretes sobre aquestes prestacions personals $\mathrm{i}$, per tant, la seva quantificació resulta impossible.

La recaptació d'impostos, tal com hem vist, generava una sèrie de despeses que estan documentades dins el llibre de clavaria. No obstant, aquesta partida es limitava a la recaptació del setzé de la collita de cereals i no es fa esment a la percepció de la resta de drets de la vila. El compartiment de l'any 1442 fou arrendat a la persona que s'oferí a fer la col·lecta pel menor salari. El mercader cerverí Pere Ferrer s'en feu càrrec per 2611.10 s.b. i va comprometre's a assumir totes les despeses de recaptació. A més, també havia de percebre els veïnatges i els deutes d'anys anteriors que li serien indicats en sengles capbreus ${ }^{58}$. Pel que fa a les imposicions, com hem dit, la modalitat de gestió era indirecta; es a dir, el municipi cedia el producte i percepció de l'impost a la persona que més diners li oferís en una

\footnotetext{
${ }^{54} L$ 'any 1442 , tal com es feia cada any quan arribava l'època de la verema, els regidors fan una crida perquè els veïns arreglessin els camins de la vila i terme, cadascun a l'alçada de llurs propietats, sota ban de 12 d.b. i pagar les obres (AHCC, FM, Crides, 1442, f. 20 v.).

${ }^{55}$ Les autoritats locals, els anys 1441 i 1442, escolliren "partidors d'aigües" perquè regulessin el reg de la vila $i$, entre altres coses, ordenaren, sota ban de 20 s.b., que les sèquies siguessin netejades $\mathrm{i}$ reparades pels terratinents, que fessin trestalladors de pedra i argamassa per regular l'aigua i que cobrissin alguns trams de la sèquia (AHCC, Fons Dalmases, capsa 26).

${ }^{56}$ Una carta dels paers de 1442 a la reina deia que els murs de la vila requerien reparacions per fer front a l'amenaça de la gent d'armes de França que volia entrar al Principat i que l'obra era tan important que “...nosaltres haiam delliberat per deenes e cinquantenes fer-hi posar les cohoperacions... e més segons nostra posibilitat fer-hi ajuda bursal e de nostres propis bens, per talla e altres medies..." (AHCC. FM. Registre de lletres, 1442, f. 110 r.-v.).

${ }^{57} \mathrm{~L}$ any 1442 , en el marc de bandositats a la vila, els regidors feien una crida perquè tothom estigués preparat en tot moment amb les armes per acudir amb el batlle $i$ paers on hi hagués aldarulls. Aiximateix, havien d'anar amb totes les armes quan sortissin de la vila per feina o altre motiu i seguir a les autoritats quan sentissin repicar el seny major per tal de prendre els malfactors (AHCC, FM, Crides, 1442, f. 18 v.). Respecte a l'host veïnal, aquell mateix any es documenta una altra crida dels paers perquè els vilatans, ordenats en desenes i cinquantenes, estiguessin preparats amb cavalls, armes $\mathrm{i}$ vitualles per trenta dies per acompanyar la senyera de Cervera contra l'abat de Ripoll (AHCC, FM, Crides, 1442, f. 15 v. i Consells, 1442, f. 39 v. -44 v.).

${ }^{58}$ AHCC, FM, Actes i Negocis (1398-1585), Compartiment, 1442, plec.
} 
subhasta $^{59}$. En ambdós casos - compartiment i imposicions- les despeses d'administració no es documenten en la clavaria. En el primer cas, perquè l'estipendi del recaptador era restat a la suma total que havia d'ingressar el clavari. En el segon, perquè el municipi estava disposat a sacrificar part dels beneficis de l'impost a canvi d'una quantitat segura i no fer-se càrrec de la gestió.

Així doncs, la constatació d'aquests mètodes o sistemes de gestió és també indicativa que les dades oferides pel llibre de clavaria de 1442 respecte a les despeses derivades de l'administració fiscal i les generades pels serveis, tant urbanístics com de seguretat i defensa, són, evidentment, molt parcials.

\section{EL FUNCIONAMENT DE LA CLAVARIA: UNA HIPÒTESI DE TREBALL}

Arribats a aquest punt, crec que podem ser conscients tant de les aportacions d'un llibre de clavaria com de les seves limitacions. No obstant, l'estudi complert de les finances municipals no sols es manifesta en la necessitat de reunir y combinar el major nombre possible de dades i sèries documentals. L'aprofundiment en aquest tema requereix també un esforç per a comprendre la mecànica de funcionament de les administracions que gestionaven els recursos municipals. En el present treball pretenem realitzar un primer pas en aquest sentit i mostrar la complexitat que assolí la clavaria a Cervera a mitjan s. XV.

Gràcies als registres del racional conservats a Cervera, podem saber, aproximadament, quin fou el ritme d'entrades o ingressos del clavari durant $l^{\prime}$ any ${ }^{60}$. Les sortides $o$ despeses també poden perioditzar-se mercés a

\footnotetext{
${ }^{59}$ Sobre l'arrendament de les imposicions, vegeu: J. BROUSSOLLE, Les impositions municipales de Barcelone de 1328 a 1462, «Estudios de Historia Moderna», V (1955), pp. 107. 112. Pel cas de Cervera, l'obra de referència continua essent: M. TURULL, La configuració, pp. 447-451.

${ }^{60} \mathrm{~L}$ 'any 1391 , el rei Joan I va concedir a la vila de Cervera la potestat d'escollir racional. Aquest nou càrrec tenia dos funcions principals: controlar la despesa municipal, donant el vist- $\mathrm{i}$ plau a les ordres de pagament (albarans) que els paers adreçaven al clavari o altres oficis, i supervisar i verificar tots els comptes derivats de l'administració municipal. El resultat d'aquesta activitat es conserva dins dos tipus de registres: els notaments del racional $i$ les dates $i$ rebudes. Els llibres de dates $i$ rebudes eren confeccionats anualment pel racional i contenien, en diferents apartats, les entrades $\mathrm{i}$ sortides de les diverses administracions municipals (recaptadors d'impostos, clavari, receptors...). Els notaments del racional abraçaven varis anys i constituïen un memorial de deutes, positius i negatius, del municipi (Vegeu: P. VERDÉS, Les sources
} 
l'anotació de la data de l'àpoca (= rebut) corresponent al final de cada assentament de la clavaria $^{61}$. Segons aquestes fonts, la distribució mensual de l'ingrés i la despesa de la clavaria de 1442 fou la següent:

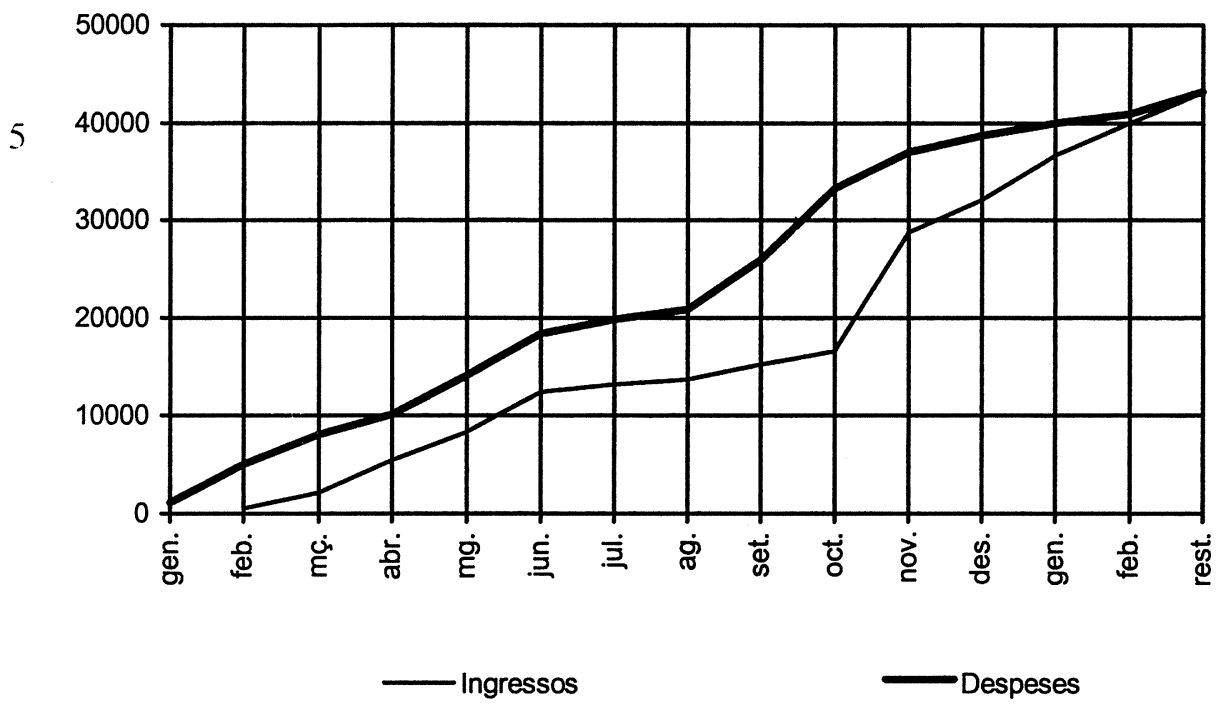

*Evolució d'ingressos i despeses en sous barcelonesos. Les xifres estan agrupades mensualment i les dades posteriors a febrer de 1443 estan incloses en l'epígraf "resta".

La gràfica, de manera sorprenent, mostra que el clavari gastava molt més que no ingressava. Com s'explica aquest fet? Ja hem dit que el propi registre de clavaria permet observar l'existència de bestretes fetes per diver-

fiscales et financières..., pp. 168-170). Gràcies a la primera de les sèries, les dates i rebudes, podem saber la cronologia dels ingressos del clavari, ja que el racional havia d'autoritzar els lliuraments de diners a aquell administrador i indicava la data de cadascuna de les entrades per a controlar en tot moment de quants diners disposava.

${ }^{61} \mathrm{~A}$ Cervera, els rebuts signats pels creditors eren anomenats àpoques i existeixen sèries municipals on eren copiats pel notari de la Paeria per ordre cronològic (vegeu: P. VERDÉs, Les sources fiscales et financières, pp. 167-168). 
sos individus al clavari, però aquesta circumstància no explica el decalatge que s'observa en el gràfic entre entrades i sortides ${ }^{62}$.

Un primer factor de correcció és el que ofereix l'anomenat peu del clavari. Des de principis del s. XV, la clavaria a Cervera era arrendada a la persona que més diners accedís a bestreure i menys salari cobrés. Jaume Ponç, sastre, signà els capítols d'arrendament de la clavaria el 23 de gener de 1442 i, entre altres pactes, oferí avançar 200 ll.b. a canví d'un salari de 19 1l. 15 s.b. Aquest prèstec sense interés havia de fer-se efectiu en el període que anava fins el mes d'octubre, moment en que s'hauria recaptat el compartiment, i, a partir de novembre, podria recuperar-lo retenint diners de la vila. En el supòsit que la vila hagués d'indemnitzar algú per un retard provocat per l'incompliment del peu, les despeses haurien de ser pagades pel clavari. Al contrari, en cas que aquest hagués avançat els diners estipulats $\mathrm{i}$ el retard es produís per manca de recursos municipals, la vila hauria d'assumir la despesa ${ }^{63}$. El resultat d'afegir els diners del peu a la gràfica, a partir del mes de gener, és el següent:

\footnotetext{
${ }^{62}$ Recordem que les bestretes consistien en avançar diners al clavari sense interés i aquest indicava en el seu llibre quan un pagament era el retorn d'una bestreta $\mathrm{i}$ en què s'havien esmerçat els diners d'aquell prèstec. Aquest tipus de crèdit també acostumava a emprar-se freqüentment en les missatgeries, quan els representants municipals- prohoms importantsavançaven els diners en els seus viatges. No obstant, aquesta circumstància no altera el ritme de despeses del gràfic, ja que el rebut es signava a l'hora de retornar els diners.

${ }^{63}$ AHCC, FM, Actes i Negocis, 1439-1449, f. 29 v.-31 r..
} 


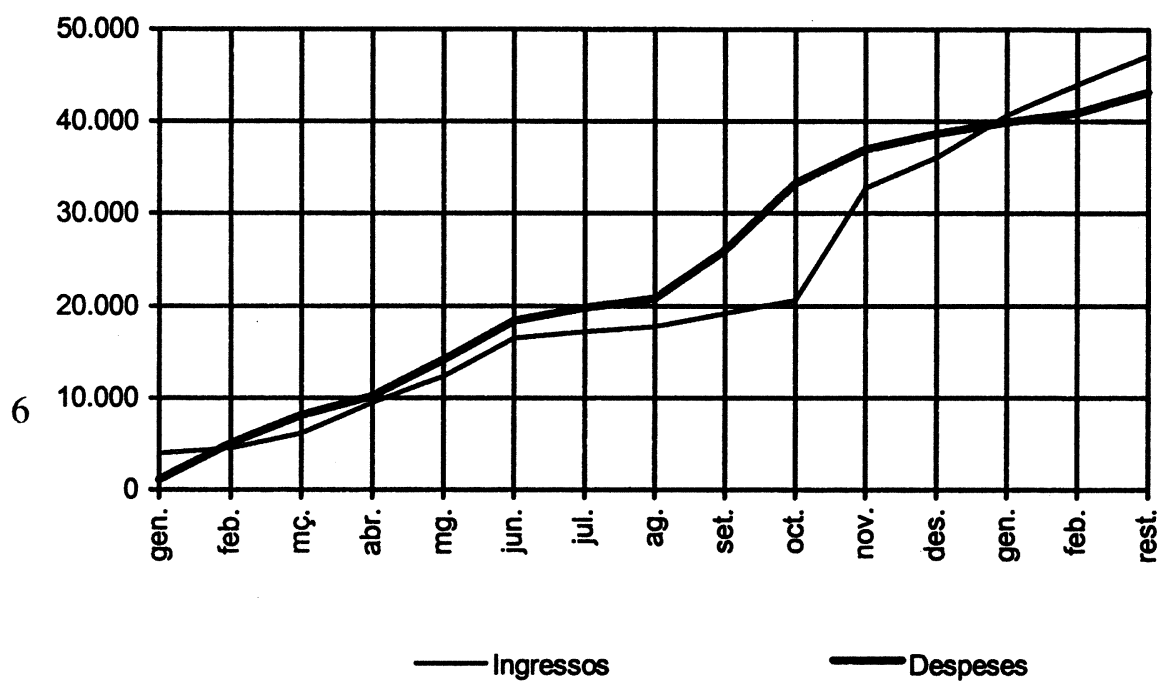

*Evolució d'ingressos i despeses en sous barcelonesos, afegint el peu de clavaria (4.000 s.b.) als ingressos a partir del mes de febrer.

Com pot apreciar-se, després d'aquesta correcció l'evolució d'ingressos i despeses va equiparant-se, però encara és clarament favorable a la despesa. A més, en aquest punt s'obren nous interrogants: com explicar l'existència d'àpoques el mes de gener quan encara no hi havia clavari? quin era el motiu que va impulsar a Jaume Ponç a arrendar una administració que, segons la gràfica, segurament no hauria de proporcionar-li cap profit econòmic?

Una possible explicació podria trobar-se en el procediment administratiu que precedia cadascun dels pagaments del clavari. En principi, semblaria lògic pensar que fer efectiva una despesa implicava una sèrie de passos: una decisió política dels regidors, l'emissió d'una ordre de pagament (=albarà), la intervenció de l'ordre per part del racional, el pagament efectiu dels diners a través del clavari i la cancel-lació de l'obligació adquirida mitjançant un rebut o àpoca. La data de l'àpoca, per tant, hauria 
d'indicar una despesa efectiva del clavari, tal com mostren més amunt les gràfiques. No obstant, hem documentat casos que indiquen que l'acció de signar el rebut era anterior a l'emissió de la citada ordre i, per tant, al moviment de caixa del clavari ${ }^{64}$. Segons aquesta hipòtesi, el creditor signaria una àpoca o rebut davant del notari de la paeria i rebria d'aquest un albarà que, després de rebre el vist-i-plau del racional, podria fer-se efectiu en caixa ${ }^{65}$. Això significaria que l'evolució de les despeses de la gràfica, basada en les dates dels rebuts, no coincidiria amb els pagaments reals efectuats pel clavari. Així doncs, després del peu del clavari, el cobrament de l'albarà constituiria el segon factor corrector que permetria equiparar ingressos i despeses.

Tot $\mathrm{i}$ això, encara no hem respost a la pregunta de quin profit esperava treure Jaume Ponç de l'arrendament de la clavaria i no podem contestar sense saber el moviment real de la seva caixa. Una de les condicions de l'arrendament d'aquest càrrec podria ser la clau per a resoldre aquesta qüestió: mensualment, el clavari havia de portar el seu llibre de dates i rebudes a la paeria perquè el notari pugués prendre'n còpia i saber que havia gastat, si havia fet efectiu el peu i de quins recursos disposava ${ }^{66}$.

\footnotetext{
${ }^{64} \mathrm{~L}$ 'any 1430, per exemple, Pere de Matabous, llaurador, cobrava 3 II. 6 s.b. en concepte d'indemnització pels danys que havia sofert en un troç de terra per les obres de reparació d'un camí. El clavari d'aquell any, però, anotava al final d'aquella despesa: “... del qual havie ja hagut albarà fet a XXIII de setembre, any MCCCCXXVIIII prop passat, lo qual albarà ha restituït al notari de la paheria... e perquè no sie vist ésser dues vegades pagat. ha n'i albarà de dit notari de la dita paheria a XXVIII de setembre, any MCCCCXXX..." (AHCC, FM Clavaria, 1430, f. 93 r.). En el registre d'àpoques de 1429. Pere de Matabous, Ilaurador, reconeixia haver rebut dels regidors i del clavari les 3 II $6 \mathrm{~s} . \mathrm{b}$ pel concepte esmentat (AHCC FM, Âpoques comunes, 1429, f. 21 r.-21 v.), però, com veiem, només va rebre una ordre de pagament (albarà) que no va fer efectiva. L'any 1430 va retornar l'albarà al notari de la paeria i, després de signar un nou rebut per aquell concepte (AHCC, FM, Àpoques comunes, 1430 , f. 26 r.), va rebre una nova ordre de pagament que, aquest cop, si que va cobrar.

${ }^{65}$ Aquest fet també corroboraria la distinció que s'estableix dins els ingressos de clavaria entre les rebudes en moneda comptat i les rebudes en albarans (ordres de pagament): "Item, més rebé del senyor en Pere Farer, pleguador dels compartiments l'any MCCCCXXXXII, en quaranta-e-quatre albarans de pensions de censals e XXIII albarans de mesions, ab IIII s.b. en diners, los quals lo dit Jacme Ponç (clavari) avie rebuts del dit Pere Farer a II de noembre, segons té en són libre rebuda del clavari, que són quatre-centes huytanta-sis II. III s. VII d.b." (AHCC, FM, Dates i rebudes, 1442, f. 70 v.). Per tant, el recaptador de l'impost directe, que havia de lliurar setmanalment el producte de la seva col-lecta (AHCC, FM, Actes i Negocis (1398-1585), Compartiment, 1442, plec), havia fet efectius els albarans emesos pels regidors $i$ ara els lliurava al clavari com si fossin un ingrés.

66 "Item, fou emprés, convengut e pactat que lo dit clavari hage e sie tengut portar lo libre de dates e rehebudes que fetes haurà $\mathrm{e}$ farà al notari de la paheria per tresladar cascun mes una vegada, sots virtut del jurament per ell prestat, per ço que sia vist quines peccúnies ha vers ells de la dita vila ni si les dites CC II. seran meses per ell en la dita claveria" (AHCC, FM, Actes
} 
El llibre de clavaria de 1442 , per tant, devia ser la còpia realitzada pel notari mensualment de la comptabilitat del clavari i la manca d'ordre cronològic en l'anotació dels diferents assentaments no seria una casualitat, sinó que probablement respondria al moviment real de caixa ${ }^{67}$. Segons aquesta interpretació poden agrupar-se les despeses mensualment, a partir dels assentaments de primer de cada mes, i el resultat és el següent ${ }^{68}$ :

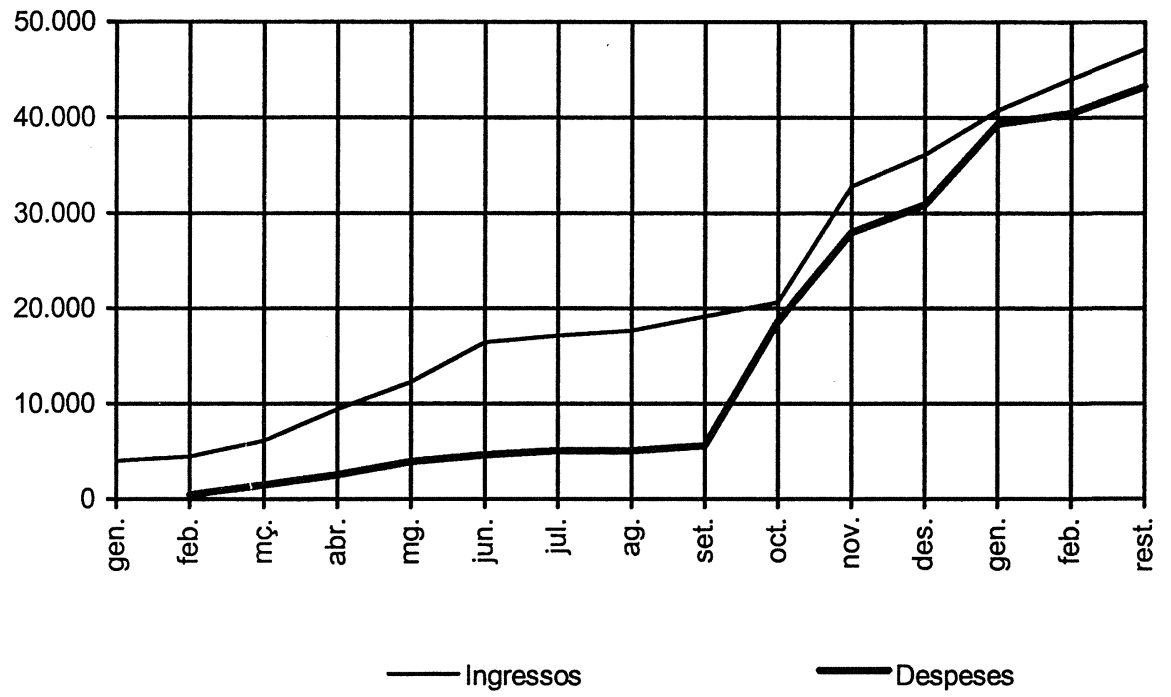
(4.000 s.b.)

i Negocis, 1439-1449, f. 29 v.-31 r.).

${ }^{67}$ Recordem que, al final de cada despesa del llibre de clavaria, s'indicava la data del rebut corresponent. Aiximateix, cal fer memòria de la distinció feta més amunt entre comptes del clavari i llibres de clavaria, així com l'ordre dels regidors de començaments del $\mathrm{s}$. XV perquè el llibre de clavaria sigués realitzat pel notari municipal en el decurs de l'any.

${ }^{68}$ Tenint en compte que al final de cada despesa del llibre de clavaria s'indica la data de l'àpoca o rebut corresponent, a partir del primer assentament de cada mes pot establir-se una divisió aproximada entre les sortides d'un més i les d'un altre. És a dir, en el moment en que el notari va copiar un assentament amb data d'u de maig, per exemple, totes les anotacions de despeses que realitzà a continuació, encara que portin data de rebut dels mesos de gener, febrer, març o abril, no foren realment pagades pel clavari amb anterioritat al primer de maig. Per aquesta raó, tots els assentaments que hi hagi entre la despesa d'u de maig i la primera despesa amb data de juny correspondran al mes de maig. De la mateixa manera, totes les despeses que hi hagi amb data de rebut d'u de juny a l'u de juliol pot considerar-se que foren pagades dins el primer més d'estiu. I així successivament. 


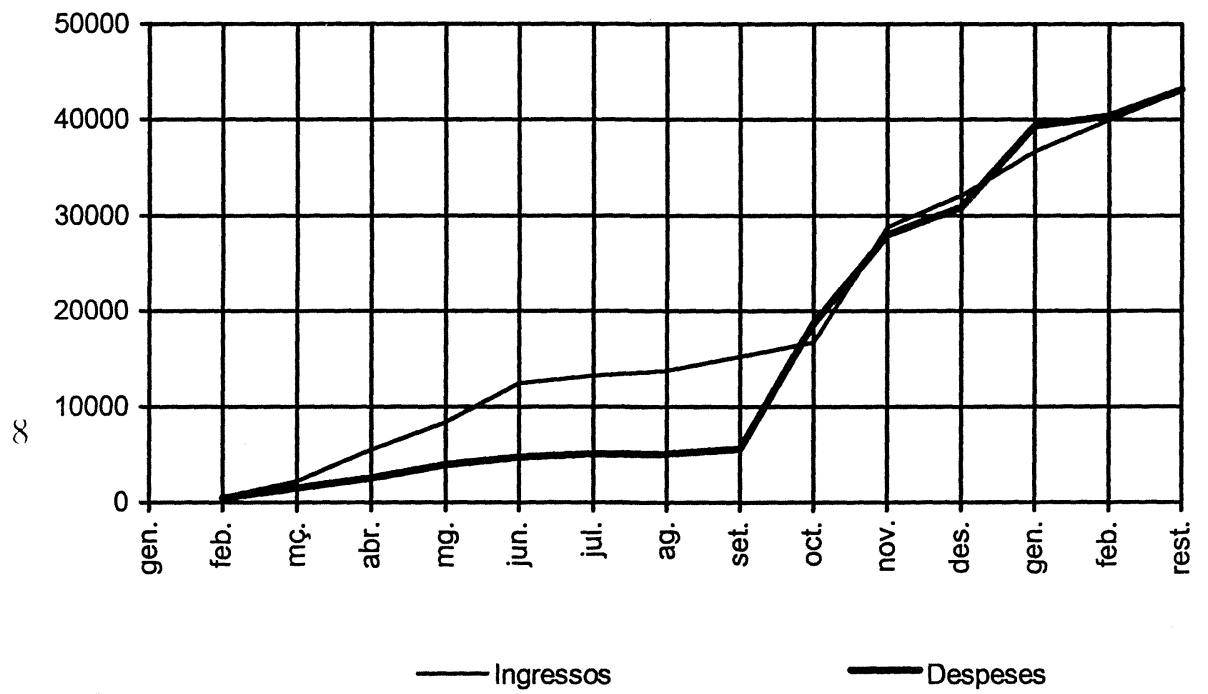

*Evolució d'ingressos i despeses en sous barcelonesos, sense comptar els diners del peu del clavari (4.000 s.b).

Encara que som conscients de que aquest criteri no pot ser completament exacte, sí que creiem que pot indicar la tendència real de la despesa. Com pot veure's, en aquesta ocasió la lògica s'imposa: el clavari té diners en tot moment per a fer front a les despeses i inclús disposa de cert superàvit durant molts mesos. D'altra banda, l'augment de la despesa, a partir de la tardor d'aquell any, també s'adiu amb l'entrada de diners procedents de la recaptació d'un impost que, en gran part, es cobrava sobre les collites de cereal, verema i safrà (agost-novembre).

Per acabar, doncs, responent a la pregunta de quin benefici podia esperar-se de l'arrendament de la clavaria, podem dir que Jaume Ponç disposava de diner municipal per negociar i especular durant el temps que tingués superàvit. Tot i que aquest marge fou més aviat escàs l'any 1442, convé indicar que el clavari a Cervera era també, en virtut d'un privilegi reial, dipositari. El dipositari era l'encarregat de rebre i custodiar els dipòsits que es lliuraven a les corts del batlle i del veguer i els diners d'altres 
administracions municipals com ara les almoines ${ }^{69}$. La clavaria, per tant, disposava d'una quantitat important de diner líquid que, podem suposar, li permetia actuar com una espècie de taula de canvi i obtenir beneficis semblants als d'un canviador ${ }^{70}$

D'aquesta hipòtesi es desprèn que no sols la quantificació dels diferents ingressos i despeses permet aprofundir en el coneixement de les finances municipals baix-medievals. Sens dubte, encara cal avançar molt més per a poder determinar amb exactitud quins eren els "negocis" del clavari a Cervera durant el $\mathrm{s}$. XV, però, de moment, la comprensió dels mecanismes de funcionament d'aquesta administració local obra noves perspectives d'estudi.

\section{CONCLUSIONS}

El clavari era el principal administrador dels fons municipals al Principat durant la Baixa Edat Mitjana i, per tant, les sèries comptables

\footnotetext{
${ }^{69}$ La figura del dipositari a Cervera durant el s. XIV ha estat estudiada per M. Turull (M. TURULL, La configuració, pp. 434-435), però aquest historiador dubta a l'hora d'identificar-lo amb el clavari. Les referències documentals del s. XV semblen esvair els dubtes i permeten afirmar que el clavari havia de rebre anualment tots els dipòsits de la vila. Veiem algunes referències properes en el temps a 1442 per il-lustrar aquest fet. L'any 1424 , per exemple, els paers deien "...que ja saben com, segons un capítol fet en los capítols de la bosseria (=clavaria), tots los depòsits deuen venir en mans e poder del bosser, per los quals depòsits havem haüt gran mercat del dit bosser, de que.s segueix proffit a la vila..." (AHCC, FM, Consells, 1424, f. $80 \mathrm{r}$.-v.). L'any 1431, un capítol de l'arrendament de la bosseria o clavaria disposava: "Item, los honorables paers e consell prometen al dit bosser que tots e qualsevol depòsits qui sien en qualsevol singulars de la vila ne dins l'any per qualsevol persones se hauran a deposar dins la vila de Cervera e vendra a mà e poder del dit bosser com pus iversosament los dits honorables pahers poran, segons lurs privilegis volen..." (AHCC, FM, Actes i Negocis, 1427-38, f. 43 r.-48 r.). I, finalment, l'any 1452 el clavari era escollit com a dipositari pel sotsveguer i sots-batlle de la vila, segons "forma de privilegi" (AHCC, FM, Actes i Negocis, 14501466, f. 14 r. -18 r.).

${ }^{70}$ De fet, la missió de la Taula de Canvi de la ciutat de Barcelona que funcionava durant aquells mateixos anys era, més o menys, la mateixa: rebre dipòsits i centralitzar els ingressos i pagaments municipals, amb l'objectiu de proporcionar crèdit a la ciutat per fer front a necessitats immediates (Anna M ${ }^{\mathrm{a}}$ ADROER i G. FELIU, Història de la Taula de Canvi de Barcelona, Caixa de Catalunya, Barcelona, 1989, pp. 30-33). Sobre el funcionament dels canviadors i les taules de canvi, vegeu també: R. CONDE, Las actividades y operaciones de la Banca barcelonesa trecentista de Pere Descaus y Andreu d'Olivella, "Revista española de financiación y contabilidad», XVIII/55 (enero-abril) i M. RIU, La banca i societat de la Corona d'Aragó, a finals de l'Edat Mitjana $i$ començaments de la Moderna, "Acta historica et archaelogica medivalia», 11-12 (1990-91), pp. 187-224. Pel que fa als origen de la taula de canvi a Cervera, vegeu: J.Ma LlOBET, La "Taula de Canvi" de Cervera y su entorno socioeconómico (1599-1715), Lleida, 1985.
} 
generades per aquest càrrec constitueixen la base primordial per a l'estudi de les finances locals. Aquesta és la premisa seguida per la major part dels estudis realitzats sobre el tema a Catalunya i a d'altres llocs de l'antiga Corona d'Aragó. Ara bé, sense negar la innegable importància de la clavaria, en el present treball hem volgut cridar l'atenció sobre el caràcter parcial d'aquesta font per a reconstruir en la seva integritat les finances municipals.

Per tal de mostrar-ho, hem triat un exemple d'aquesta comptabilitat, el llibre de clavaria de la vila de Cervera de l'any 1442, i hem vist quina era la imatge que oferia. La font estava estructurada en un apartat d'ingressos (rebudes) i un altre de despeses (dates). Dins els ingressos de la clavaria es distingien tres capítols: l'impost directe, l'impost indirecte i la resta d'entrades. L'impost directe (setzé o compartiment) constituïa la partida més important d'ingressos de la clavaria, amb el $60 \%$ del total. En segon lloc, el 30\% dels ingressos procedien d'una part molt minsa de l'impost indirecte (imposicions) arrendat aquell any. La resta de rebudes, encara no el 10\%, corresponien a un capítol de varia, dins del qual adquirien certa relevància els veïnatges. Finalment, hem destacat que dins les entrades del llibre de clavaria estudiat hi havia una manca, només aparent, del recurs a l'endeutament i que la percepció d'endarreriments tenia una importància considerable, ja que suposaven més d'un $35 \%$ del total d'ingressos.

Pel que fa a les despeses, aquestes podien agrupar-se en pagaments destinats a la satisfació de l'endeutament contret pel municipi, al funcionament de l'aparell administratiu i a la prestació de serveis a la comunitat. El finançament de l'endeutament a llarg plaç (censals morts) era la principal despesa municipal de 1442, amb el $65 \%$ del total. El segon capítol en importància era l'administració municipal, que absorbia el $25 \%$ de la despesa. En tercer i darrer lloc, sorprenia l'escassa relevància econòmica dels serveis prestat pel municipi a la comunitat; menys del $10 \%$ de les sortides. L'anàlisi de la despesa es tancava amb la quantificació del ròssec satisfet per la clavaria de 1442: prop d'un $15 \%$ del total de dates correponien a endarreriments i la major part eren interessos del deute.

Aquesta era la imatge de l'activitat econòmica del municipi cerverí l'any 1442, segons el llibre de clavaria. La font estudiada, però, tenia serioses limitacions i l'existència d'altres administracions o caixes paral-leles relativitzaven els seus resultats. La clavaria coexistia amb altres administracions municipals, com ara: la receptoria, l'obra de l'esg! èsia parroquial, les 
institucions benèfiques i diversos oficis que funcionaven de manera independent.

La receptoria tenia la funció de gestionar el pagament dels interessos i l'amortització d'una part important de l'endeutament censal del municipi cerverí, concretament el dels creditors de la ciutat de Barcelona. El producte de l'arrendament de la major part de l'impost indirecte (imposicions) estava assignat a aquest fi i, a més, també servia per a pagar un antic tribut senyorial (quèstia) que, en aquells moments, era satisfet a un ciutadà barceloní. Les dades de la receptoria, per tant, havien de sumar-se a la clavaria i la xifra resultant fa palesa la importància aclaparadora dels ingressos procedents de l'impost indirecte (60\%), així com les despeses derivades de l'endeutament censal (70\%) dins les finances municipals.

No obstant, aquesta tendència extrema era corregida per l'actuació d'altres administracions, dedicades, bàsicament, a la prestació de serveis a la comunitat; un aspecte que, com hem vist, era força marginal dins el llibre de clavaria. La despesa municipal en obres de 1442 també incloïa l'edificació de l'esglèsia parroquial de $\mathrm{S}^{\mathrm{a}}$ Maria de Cervera. Aquesta obra diposava d'una administració pròpia que funcionà regularment mentre durà la construcció del temple (s. XIII-XVI). D'altra banda, la manca de referències a beneficència dins la clavaria s'explicava per l'existència d'una sèrie d'institucions municipals paral·leles. L'assistència als necessitats era tasca dels procuradors dels hospitals, del Censal de la Caritat, dels infants gitats o dels bacins i cadascun d'aquests càrrecs havia de retre'n comptes al final de llur regiment. Finalment, l'escàs interés que, segons el llibre de clavaria, les autoritats locals semblaven mostrar pel desenvolupament econòmic de la vila es veia desmentit pels serveis que oferia un grup d'oficis municipals, que funcionaven de manera autònoma gràcies al cobrament de taxes i multes. La manufactura i el comerç a la població eren controlats pels mostaçafs, pesadors, mesuradors i veedors dels diferents oficis, metre que els guardes del terme o els partidors d'aigües vetllaven per la bona convivència entre els diferents sectors agropecuaris. Així doncs, tal com feiem amb la receptoria, caldria sumar els ingressos i despeses de les administracions suara esmentades a la clavaria. Malauradament, però, la comptabilitat d'aquestes institucions menors quasi no s'ha conservat a Cervera i la seva quantificació resultava impossible.

Aquest problema es repetia en relació a una sèrie d'actuacions municipals que no deixaven rastre en la comptabilitat local. D'una banda, els serveis personals que els veïns de la vila realitzaven en els àmbits de les obres públiques i de la seguretat i defensa. De l'altra, la gestió indirecta dels 
impostos: l'arrendament al millor postor o al menys dient evitava les despeses derivades de la gestió fiscal, encara que això anés en detriment dels ingressos o escapés al control administratiu dels regidors. Per tant, els resultats de la clavaria respecte a l'administració i, altra vegada, els serveis havien de ser també reevaluats atenent a aquesta circumstància.

Finalment, un darrer factor corrector en l'anàlisi de la clavaria de 1442 era l'activitat creditícia que s'ocultava darrera el funcionament d'aquesta institució. Com hem vist, dins els ingressos no hi havia cap referència a l'endeutament i sols podia adduir-se la seva presència en el cas de les bestretes. Aquest fet, però, resultava força sorprenent quan s'observava l'evolució dels ingressos i dels rebuts dels pagaments fets pel clavari al llarg de l'any: la despesa era sempre superior als ingressos i sols al final de l'exercici s'equilibraven les partides. L'arrendament de la clavaria i l'existència d'un avançament de capital (peu) per part de l'arrendatari atenuava el decalatge esmentat, però en absolut resolia el problema financer. Alhora, un nou interrogant s'obria quan descobriem que hi havia rebuts anteriors a l'elecció del clavari i maldavem per entendre quin profit podia treure el clavari d'aquella operació financera. La revisió del procediment de la despesa amagava la resposta: els rebuts (àpoques) no eren indicatius del moviment de caixa, ja que eren signats abans de rebre la corresponent ordre de pagament (albarà); que constituïa una especie de xec al portador. La resolució de l'incògnita es completava amb l'examen de la comptabilitat: el llibre de clavaria estudiat era una còpia dels comptes del clavari, realitzada mensualment pel notari municipal i l'ordre d'anotació dels diferents assentaments, tot i no correspondre amb la cronologia dels rebuts, responia a l'evolució real de la despesa. Aquesta hipòtesi permetia comprovar que el clavari sempre va disposar de recursos municipals per a fer front a les despeses, inclús de superàvit durant molts mesos. Durant aquest darrer període, l'administrador disposava d'una quantitat important de diner líquid per a negociar i especular. La coincidència, en virtut d'un privilegi reial, del càrrec de clavari municipal amb el de dipositari de les corts del batlle i el veguer acabava d'explicar l'interés per a arrendar el càrrec, que esdevenia un clar precedent de la taula de canvi.

Tot plegat permet copsar l'abast real de les finances del municipi de Cervera durant el s. XV, així com les limitacions de les fonts a l'hora d'analitzar-lo. Segurament, aquest anàlisi de la clavaria podria aprofundir-se $\mathrm{i}$, fins i tot, ampliar-se per la banda de la receptoria o de la recaptació 
d'impostos. La meva intenció es continuar per aquest camí i poder oferir nous resultats en d'altres estudis.

\section{RÉSUMÉ}

Dans les municipes catalans du Bas Moyen Âge, le clavari était l'administrateur majeur des finances. Les comptes fournis par ce fonctionnaire ont été la source principale des études concernant les finances locales, en Catalogne et dans d'autres régions de l'ancien Royaume d'Aragon. Ce travail veux attirer l'attention sur les limites de cette source pour reconstruire les finances integrales de la municipalité. On se sert, comme exemple, du "Llibre del clavari" de la ville de Cervera de 1442. L'information fournie par ce registre est ici analysée; ensuite, on amplifie la perspective vers d'autres administrations municipales contemporaines du clavari; et, enfin, on approfondi sur le fonctionnement de la clavaria.

\section{SUMMARY}

The clavari was the principal financial manager of the town councils of the Late Middle Ages, and his account books should constitute the foundations of any study of local finances for that period. Such studies of municipalities of Catalonia and the rest of the Crown of Aragon have indeed taken such an approach.

The present article aims to draw readers'attention to the possibilities of the Llibres de Clavaria in order to reconstruct the council finances, and to show this, it is studied the Llibre de clavaria of the town of Cervera, dated in 1442. An analysis of this book is followed by a comparative examination of other towns and, finally, a detailed study of the institution of the clavaria itsef. 